\title{
A case of skin graft versus host disease after autologus stem cell transplantation
}

\author{
Hacer Gozde $\mathrm{G}^{1 *}$, Mehmet Ali $\mathrm{E}^{2}$, Irfan $\mathrm{K}^{2}$ and Emin $\mathrm{K}^{2}$ \\ ${ }^{1}$ Inonu University, Internal medicine department, Turkey \\ ${ }^{2}$ Inonu University, Stem cell transplantation center, Turkey
}

\section{Introduction}

Multiple myeloma (MM) is one of the most common indication for autologous hematopoietic stem cell transplantation (HSCT) in North America [1]. Despite occurring in up to $50 \%$ of patients undergoing allogeneic HSCT, the incidence of graft-versus-host disease (GVHD) after autologous HSCT is reportedly only $5-20 \%$ [2]. Acute graft versus host disease is characterized by involvement of skin and gastrointestinal system. Skin eruptions, diarrhea and liver function test abnormalities can be seen . Auto-GVHD is usually less severe than allogeneic GVHD, and it can be one of the manifestations of engraftment syndrome with release of inflammatory cytokines and infiltration of auto-reactive $\mathrm{T}$ cells into affected tissue. Seventy-nine percent of patients respond well to corticosteroids without evidence of recurrence. However, cases of severe auto-GVHD lacking good response to corticosteroids have been reported, most notably in MM patients. In literature there are four cases of gastrointestinal system GVHD after autologous stem cell transplantation in multiple myeloma patients [3].

\section{Case}

38 years old male patient diagnosed kappa chain multiple myeloma. He got four cycle of VCD (bortezomib cyclophosphamide and dexamethasone) regimen. After chemotherapy patients was on remisson. He got mobilization regimen with 5 gr cyclophosphamide and 5 gr uromitexan. He was done autologous stem cell transplantation succesfully. After the transplantation he admitted outpatient policlinics regularly. Day +33 he admitted hospital with diarrehea. Stool and blood examinations was done. Direct microscopy of stool has intense leucosyte, there was no parasite. Enteric bacteria panel and C.difficle pcr tests were negative. He was seen by infectious specialist too. He got one week metronidasol treatment but there was no complaint relief. $\mathrm{He}$ was hospitalized. He had mild liver function test elevation too. $\mathrm{He}$ was seen by gastroenterology and infectious disease specialists. While he was in hospital he had maculopapülar rash on his trunk, face and extensor sides. He was seen by dermatology specialist and skin biopsy was taken, meanwhile metilprednisolone was given because suspicious of acute graft versus host disease. After medication his complaints gets milder (Figures 1 and 2). We were able to cessate metilprednisolone to 8 $\mathrm{mg}$ but unable to stop it, so photopheresis treatment was begun. Finally the patient has no skin eruption and diarrehea after photopheresis cycles. Now, he comes check ups regularly and he does well.

\section{Conclusion}

Our case is the first skin GHVD after autologous stem cell transplantation up to the literatüre. It is important to further the understanding of the various presentations of auto-GVHD, like

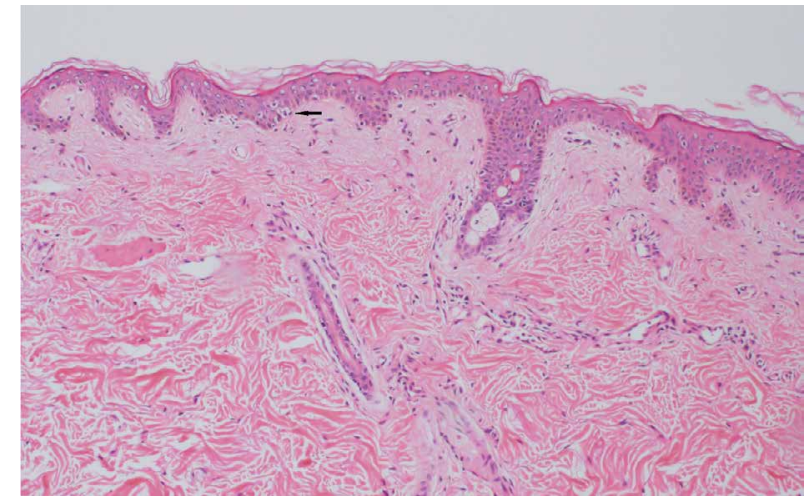

Figure 1. Epidermal focal hydropic degeneration (arrow) and dilated vessels in the dermis, $\mathrm{H} \& \mathrm{E} \times 100$

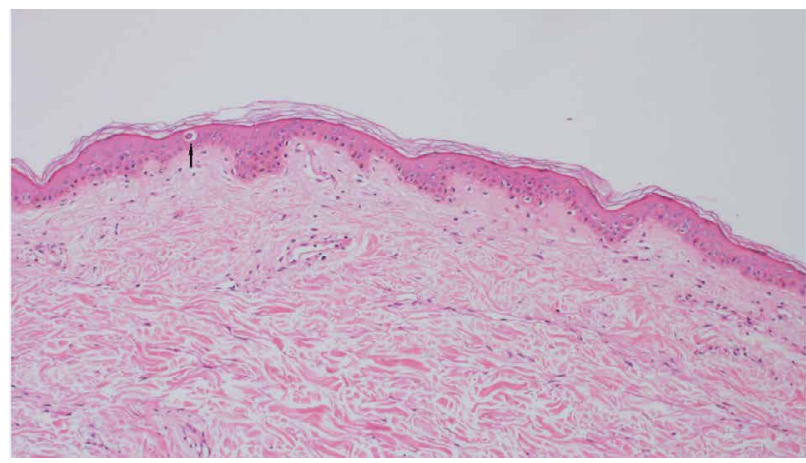

Figure 2. Scattered apoptotic keratinocyte (arrow), H\&E x100

gastrointestinal system and skin, the potential contributing factors that may predispose patients to auto-GVHD, and to highlight effective treatment approaches. With our skin auto-GVHD case, all five auto GVHD cases are in mulitple myeloma patients . Maybe it is because of the particular pathway in engrafment of stem cells in multiple myeloma patients. It is important to keep in mind GVHD can occur after autologous stem cell transplantation. In the suspicious of skin GVHD, skin biopsy should be taken. Corticosteroids and some additional therapies like photopheresis should be given immediately. Maybe the most important point is whether there is a relationship with auto

${ }^{\star}$ Correspondence to: Hacer Gozde GUL, Inonu University, Internal medicine department, Turkey, E-mail: gozdegul44@hotmail.com

Received: January 04, 2019; Accepted: January 14, 2019; Published: January 16, 2019 
GVHD and multiple myeloma pathogenesis to enlight the factors that affect success of the engraftment.

\section{References}

1. Lazarus HM, Sommers SR, Arfons LM, Fu P, Ataergin SA, et al. (2011) Spontaneous autologous graft-versus-host disease in plasma cell myeloma autograft recipients: Flow cytometric analysis of hematopoietic progenitor cell grafts. Biol Blood Marrow Transplant 17: 970-978.
2. Goddard DS, Ruben BS, Mathes ED, Nixon M, Wolf J, et al. (2010) A case of severe cutaneous, GI and liver GVHD in a patient with multiple myeloma, status-post-second auto-SCT. Bone Marrow Transplant 45: 409-411. [Crossref]

3. Hammami MB, Talkin R, Goyals SD, Lai JP, Al-Taee AM, et al. (2018) Autologous graft-versus-host disease of the gastrointestinal tract in patients with multiple myeloma and hematopoietic stem cell transplantation. Gastroenterology Res 11: 52-57. [Crossref]

Copyright: (C2019 Hacer Gozde G. This is an open-access article distributed under the terms of the Creative Commons Attribution License, which permits unrestricted use, distribution, and reproduction in any medium, provided the original author and source are credited. 